\title{
Cranberries and Urinary Tract Infections in Women
}

\author{
Francisco $\mathrm{SB}^{1}{ }^{*}$, Sara $\mathrm{MB}^{1}$, Ana María $\mathrm{OB}^{2}$ and Emilio $\mathrm{LA}^{1}$ \\ ${ }^{1}$ Urology Department, University General Hospital, Valencia, Spain \\ ${ }^{2}$ Nephrology Department, Lluis Alcanyis Hospital, Xátiva, Spain
}

Mini Review

Volume 2 Issue 2

Received Date: December 18, 2016

Published Date: April 10, 2017

*Corresponding author: Sánchez Ballester Francisco, Urology Department, University General Hospital, Valencia, Spain,

Email: sanchezballester@gmail.com

\section{Abstract}

Background: Urinary tract infections (UTI) are the most common bacterial infection. Antibiotic therapy is used after establishing a presumptive diagnosis of UTI. Cranberries have been traditionally used to prevent recurrent UTIs. The purpose of this meta-analysis was to determine the effectiveness of cranberries for prevention of UTIs.

Methods: A literature search was performed to identify clinical trials and systematic meta-analyses. Electronic databases were used, including PubMed and Cochrane.

Results: Five meta-analyses were considered. Some clinical studies have supported cranberries benefits; however the effectiveness of the cranberry on prevention of recurrent UTIs remains controversial.

Keywords: Urinary Tract Infection; Cranberry; Antibiotics; Proanthocyanidin; Meta-analyses.

\section{Background}

Urinary tract infections (UTIs) are the most common bacterial infection and also a common cause of morbidity. The overall prevalence of bacteria in women has been estimated at $3.5 \%$, increasing with age. About 30\% of women will have a symptomatic UTI requiring antimicrobial therapy by the age of 24 , and nearly half of all women will experience a UTI during their lifetime. Once a patient has an UTI will be more likely to develop subsequent infections. A recurrent infection occurs after a solved infection. However, we have to consider two types of recurrent infections: reinfection describes a new infection by bacteria from outside the urinary tract; and bacterial persistence refers to a UTI caused by the same bacteria reemerging from a focus within the urinary tract (infection stones, chronic bacterial prostatitis, and foreign bodies).
That is why antimicrobial prophylaxis becomes important for prevention of reinfections of the urinary tract. However, repetitive use of antibiotics is a risk factor for development of multidrug antimicrobial resistance. Recently non-antibiotic prophylaxis is becoming more popular for the treatment of women with recurrent UTIs (rUTIs) to avoid antibiotic side effects. Uropathogenic Escherichia coli (UPEC) is the etiological agent in about $90 \%$ of community acquired infections and more than $50 \%$ of those acquired in hospitals. Most uropathogenic strains express fimbriae on the cell surface. There are two different types of fimbriae: type 1 fimbriae, mannosesensitive; and $P$ fimbriae, mannose-resistant. UPEC strains use the fimbriae to bind to uroepithelial cells or catheter surfaces.

Type 1 fimbriae bind to mucous, rich in mannose receptors. It explains why they mediate the initial phases of urinary infection. However, the $\mathrm{P}$ fimbriae are associated with the bacteria invasivity. They guarantee 
mannose-independent adhesion, ensuring the urinary infection by stopping bacteria being eliminated together with the mucous in the urine [1]. Cranberries have been used in the prevention of UTIs for many years. They contain proanthocyanidin (PACs) type A that inhibits $\mathrm{P}$ fimbriae adhesion to uroepithelial cells. There are different cranberry presentations (juice, tablets) and depending which type the composition and the contents of PACs can change [1].

It exists also a correlation between cranberries and other benefits, such as attenuation of the development of uropathogen reservoirs and suppression of inflammatory cascades [2-4]. Cranberries and UTIs have been evaluated in evidence-based reviews and meta- analyses and they have resulted in conflicting conclusions. There is not a standard method to measure PAC contents on American cranberry (AC) extract hence the difference between antiadhesive effects against Escherichia coli.

\section{Methods}

A literature search was performed to identify clinical trials and systematic meta-analyses to be included in this article. Clinical trials that can provide additional information on the possible cranberry benefits in women suffering from rUTIs also have been considered.

\section{Results}

\section{Description of the studies}

We considered 5 meta-analyses: 3 were from the Cochrane Collaboration [5-7] the latest one from 2012 was an update of the two previous publications; and the 2 others were by Wang et al. [8] and Beerepoot et al. [9]. A summary of these systematic reviews is on Table 1.

The 2004 Cochrane review [7] included 7 studies. The effectiveness of cranberry juice or cranberry-lingonberry juice versus placebo juice or water was evaluated in six studies, and the effectiveness of cranberries tablets versus placebo was evaluated in two studies (one study evaluated both juice and tablets). In two good quality randomized controlled trials (RCTs), cranberry products significantly reduced the incidence of UTIs at 12 months (RR 0.61, 95 CI 0.40-0.91) compared with placebo in women.

\begin{tabular}{|c|c|c|}
\hline Reference & Objective & Conclusión \\
\hline Jepson et al. (2012) [6] & $\begin{array}{c}\text { To assess effectiveness of cranberry } \\
\text { products in preventing UTIs }\end{array}$ & $\begin{array}{c}\text { Cranberry juice is less effective than } \\
\text { previously seen. Cranberry cannot be } \\
\text { recommended for the prevention of } \\
\text { UTIs }\end{array}$ \\
\hline Jepson and Craig (2008) [5] & $\begin{array}{c}\text { To assess effectiveness of cranberry } \\
\text { products in preventing UTIs } \\
\text { To assess effectiveness of cranberry } \\
\text { products in preventing UTIs }\end{array}$ & $\begin{array}{c}\text { Cranberry significantly reduced the } \\
\text { incidence of UTIs }\end{array}$ \\
\hline Jepson et al. (2004) [7] & $\begin{array}{c}\text { Cranberry juice may decrease the } \\
\text { incidence of UTIs }\end{array}$ \\
\hline Wang et al. (2012) [8] & $\begin{array}{c}\text { To evaluate cranberry products for the } \\
\text { prevention of UTIs }\end{array}$ & $\begin{array}{c}\text { Cranberry has a protective effect } \\
\text { against UTIs }\end{array}$ \\
\hline Beerepoot et al. (2013) [9] & $\begin{array}{c}\text { To assess the effectiveness of cranberry in } \\
\text { adults with recurrent UTIs }\end{array}$ & $\begin{array}{c}\text { Cranberry reduces the recurrence of } \\
\text { UTIs }\end{array}$ \\
\hline
\end{tabular}

Table 1: Summary of systematic reviews on cranberry and UTIs.

There was no significant difference in the incidence of UTIs between cranberry juice versus cranberry capsules.

The 2008 Cochrane review [5] included 10 studies $(n=1049)$. Cranberry/cranberry-lingonberry juice versus placebo, juice or water was evaluated in seven studies, and cranberry tablets versus placebo in four studies (one study evaluated both juice and tablets). The Cochrane review reported that the consumption of cranberry significantly reduced UTI incidence in 12 months compared with placebo consumption (RR: 0.65 , 95\% CI $0.46-0.90$ ), wich is a similar result than the previous Cochrane review. Cranberry products were more effective reducing the incidence of UTIs in women with rUTIs, than elderly men and patients requiring catheterization. Six studies were not included in the meta-analyses due to methodological issues or lack of available data.

The new 2012 Cochrane review [6] is an updated version. It included a total of 24 studies with 4473 patients. So 14 studies have been added to the 10 studies in the previous 2008 review. Thirteen studies (2380 patients) evaluated cranberry juice/concentrate; nine studies (1032 patients) evaluated cranberry tablets or capsules; one study compared cranberry juice and tablets; and one study compared cranberry capsules and tablets. 
The control arms were placebo, no treatment, water, methamine hippurate, antibiotics or lactobacillus. Data included in the meta-analyses showed that, compared with placebo, water or no treatment, cranberry products did not significantly reduce the occurrence of symptomatic UTI overall (RR $0.86,95 \%$ CI $0.71-1.04$ ) or for any of the subgroups: women with rUTI (RR $0.74 ; 95 \%$ CI 0.42-1.31), older people, pregnant women, children with rUTI, cancer patients or people with neuropathic bladder or spinal injury. The effectiveness of cranberry was not significantly different to antibiotics for women (RR 1.31, 95\% CI 0.85-2.02). So the addition of 14 further studies suggests that cranberry juice is less effective than previously indicated. Although some of small studies demonstrated a small benefit for women with rUTIs, there were no statistically significant differences when the results of a much larger study were included. So this 2012 review concludes that cranberry juice cannot currently be recommended for the prevention of UTIs.

The aim of Wang et al. [8] analyses was to evaluate cranberry-containing products for the prevention of UTI and to examine the factors influencing their effectiveness. It included RCTs that compared cranberry-containing products vs placebo or no treatment for prevention of UTI. A total of 13 RCTs were selected. 1616 patients were included and they categorized each study population into subgroup analysis: women with rUTIs, elderly patients, patients with neuropathic bladder, pregnant women and children. Subgroup analysis demonstrated that cranberrycontaining products seemed to be more effective in women with rUTI (RR: 0.53 ; 95\% CI: $0.33,0.83$ ), although the $\mathrm{P}$ values were not significant. These results were similar to the results of the review by Jepson and Craig [5].
The Beerepoot et al. [9] objective was to assess the effectiveness, tolerability and safety of nonantibiotic prophylaxis in adults with rUTIs. It included RCTs in adults with rUTIs comparing nonantibiotic prophylaxis to placebo or no treatment. It included 17 studies with data on 2165 patients, ages between 20 and 50 years old. The sample size varied between 44 and 453 , with follow-up between 20 weeks and 12 months. The analyses were not stratified by gender. In these meta-analyses many nonantibiotic prophylaxis products were studied, and to assess the effectiveness of cranberry prophylaxis 2 studies that compared cranberry products to placebo or no treatment in women were identified. In their metaanalyses cranberry products reduced UTI recurrence (RR $0.53,95 \%$ CI 0.33-0.83).

Kevin et al. [10] report a recent double blind, randomized, placebo-controlled trial that was designed to assess the effects of the consumption of a cranberry beverage on episodes of clinical (symptomatic) UTI in healthy women. The study was conducted at 17clinical research sites in the United States and at one clinical research center in France. In this study daily consumption of a cranberry beverage for 24 weeks produced a 39\% (95\% CI: 9\%, $59 \%)$ reduction in clinical UTI episodes. The rate of clinical UTI with pyuria episodes was also reduced by 37\% (95\% CI: 3\%, 60\%) although no difference between the groups was observed for microbiologically positive UTIs. A course of antibiotic therapy for a clinical UTI was prevented for every 3.2 woman-years (95\% CI: 2.0, 13.1 woman-years) (adjusted for antibiotic use) of the cranberry intervention. These results suggest that the consumption of cranberry is a useful strategy for reducing recurrent clinical UTI episodes and antibiotic use that is associated with the treatment of these events.

\begin{tabular}{|c|c|c|c|c|}
\hline Study & $\mathbf{N}$ & Study design & Treatment & Results \\
\hline $\begin{array}{l}\text { Walker et al. } \\
\text { (1997) }\end{array}$ & $\begin{array}{l}19 \text { young } \\
\text { women with } \\
\text { recurrent UTIs }\end{array}$ & $\begin{array}{l}\text { Double-blind, } \\
\text { randomized, } \\
\text { placebo-controlled, } \\
\text { crossover trial }\end{array}$ & $\begin{array}{l}400 \text { mg of cranberry } \\
\text { capsules }\end{array}$ & $\begin{array}{l}\text { Withdrawal rate of } 47.4 \% \text {. } \\
\text { UTI incidences were } \\
2.4 / \text { subject-year-cranberry } \\
\text { and } 6.0 / \text { subject-year- } \\
\text { placebo }(\mathrm{p}<0.005) .\end{array}$ \\
\hline Stothers (2002) & $\begin{array}{l}150 \text { women with } \\
\text { recurrent UTIs }\end{array}$ & $\begin{array}{l}\text { Double-blind, } \\
\text { randomized, } \\
\text { placebo-controlled }\end{array}$ & $\begin{array}{l}250 \mathrm{ml} \text { pure cranberry } \\
\text { juice or concentrated } \\
\text { cranberry tablets }\end{array}$ & $\begin{array}{c}\text { UTIs were } 72 \% \text { (placebo), } \\
30 \% \text { (juice; }<<0.05 \text { ) and } \\
39 \% \text { (tablets; } p<0.05 \text { ). }\end{array}$ \\
\hline $\begin{array}{c}\text { Barbosa-Cesnik } \\
\text { (2010) }\end{array}$ & $\begin{array}{c}319 \text { young } \\
\text { women with } \\
\text { previous UTIs }\end{array}$ & $\begin{array}{c}\text { Double-blind, } \\
\text { randomized, } \\
\text { placebo-controlled }\end{array}$ & $\begin{array}{c}8 \text { oz. of } 27 \% \text { cranberry } \\
\text { juice }\end{array}$ & $\begin{array}{c}\text { Recurrence rates of UTIs } \\
\text { were } 19.3 \% \text { for cranberry } \\
\text { treatment and } 14.6 \% \text { for } \\
\text { placebo }(\mathrm{p}=0.21) .\end{array}$ \\
\hline $\begin{array}{l}\text { Kontiokari et al. } \\
\qquad \text { (2001) }\end{array}$ & $\begin{array}{c}150 \text { young } \\
\text { women with } \\
\text { previous UTIs }\end{array}$ & $\begin{array}{l}\text { Double-blind, } \\
\text { randomized, } \\
\text { placebo-controlled }\end{array}$ & $\begin{array}{l}50 \mathrm{ml} \text { of cranberry- } \\
\text { lingonberry juice ( } 7.5 \mathrm{~g} \text { of } \\
\text { cranberries);Lactobacillus }\end{array}$ & $\begin{array}{l}20 \% \text { reduction in UTIs in } \\
\text { cranberry group. } \\
\text { Recurrence rate of UTIs }\end{array}$ \\
\hline
\end{tabular}




\begin{tabular}{|c|c|c|c|c|}
\hline & & & $\begin{array}{l}\text { GG } 100 \mathrm{ml} / \text { day; or } \\
\text { controls, }\end{array}$ & $\begin{array}{l}\text { lower in cranberry group } \\
\text { (at six months, } \mathrm{p}=0.014 \text { and } \\
\text { at } 12 \text { months, } \mathrm{p}=0.052 \text { ). }\end{array}$ \\
\hline $\begin{array}{l}\text { Avorn et al. } \\
\text { (1994) }\end{array}$ & $\begin{array}{l}153 \text { elderly } \\
\text { women }\end{array}$ & $\begin{array}{c}\text { Double-blind, } \\
\text { randomized, } \\
\text { placebo-controlled }\end{array}$ & $\begin{array}{c}300 \mathrm{ml} / \text { day of cranberry } \\
\text { juice and placebo }\end{array}$ & $\begin{array}{l}\text { Bacteriuria in } 28.1 \% \text { in } \\
\text { placebo group and } 15 \% \text { in } \\
\text { cranberry group (no } \\
\text { significance). OR of } 0.42 \text { for } \\
\text { bacteriuria in cranberry. }\end{array}$ \\
\hline $\begin{array}{l}\text { McMurdo et al. } \\
\text { (2009) }\end{array}$ & $\begin{array}{c}137 \text { women } \\
\text { aged }>45 \text { years } \\
\text { with recurrent } \\
\text { UTIs }\end{array}$ & $\begin{array}{l}\text { Double-blind, } \\
\text { randomized } \\
\text { controlled trial }\end{array}$ & $\begin{array}{l}500 \mathrm{mg} \text { of cranberry } \\
\text { extract or } 100 \mathrm{mg} \text { of } \\
\text { trimethoprim }\end{array}$ & $\begin{array}{l}25 \text { UTIs in the cranberry } \\
\text { group and } 14 \text { in the } \\
\text { trimethoprim group; } \\
\text { relative risk } \\
1.616, p=0.084 .\end{array}$ \\
\hline $\begin{array}{l}\text { Wing et al. } \\
\text { (2008) }\end{array}$ & $\begin{array}{c}188 \text { pregnant } \\
\text { women; } \\
\text { gestation of }<16 \\
\text { weeks }\end{array}$ & $\begin{array}{l}\text { Double-blind, } \\
\text { randomized, } \\
\text { placebo-controlled }\end{array}$ & $\begin{array}{l}240 \mathrm{mg} \text { of cranberry juice } \\
(27 \%) 3 \text { times/day (group } \\
\text { A) or } 240 \mathrm{mg} \text { once daily } \\
\text { (group B) or placebo } \\
\text { (group C) }\end{array}$ & $\begin{array}{l}\text { Withdrawal rate of } 38.8 \% \\
\text { (A 50.7\%; B 39.7\%; C } \\
\text { 55.5\%). No significant } \\
\text { differences between the } \\
\text { groups ( } \mathrm{p}=0.71 \text { ) }\end{array}$ \\
\hline $\begin{array}{l}\text { Ferrara et al. } \\
\quad(2009)\end{array}$ & $\begin{array}{l}84 \text { girls with } \\
\text { recurrent UTIs }\end{array}$ & $\begin{array}{l}\text { Randomized } \\
\text { controlled }\end{array}$ & $\begin{array}{l}\text { Cranberry-lingonberry } \\
\text { juice } 50 \mathrm{ml} / \text { day } \\
\text { (n=27); Lactobacillus } \\
\text { GG } 100 \mathrm{ml} 5 \text { days/month } \\
(\mathrm{n}=26) ; \text { control }(\mathrm{n}=27)\end{array}$ & $\begin{array}{l}\text { UTIs in } 18.5 \%(5 / 27) \text { of } \\
\text { patients in the first group } \\
\text { versus } 42.3 \% \text { in the second } \\
\text { and } 48.1 \% \text { in the control } \\
\text { group }(\mathrm{p}<0.05)\end{array}$ \\
\hline
\end{tabular}

Table 2: Clinical trials of cranberry products for UTI prevention in different populations [11].

Recently also, Singh et al. report a study that compares standardized cranberry versus placebo [12] for12 weeks in 72 patients. It concludes that standardized cranberry extract is superior to placebo in terms of bacterial adhesion; MHRA bacterial negativity; urine pH reduction; and in preventing UTI (dysuria, bacteriuria and pyuria). No in vitro antibacterial activity of cranberry could be demonstrated.

A study about postcoitalurinary tract infection (PCUTI)using $240 \mathrm{mg}$ PAC (Cysticlean) in 20 patients showed a reduction in the number of UTIs in this group of patients [13]. Other commercial preparations of cranberry have also reported a reduction of urinary tract infections [14].

In older women, astudy showed that $300 \mathrm{~mL}$ of cranberry juice cocktail could reduce the laboratory evidence of UTI at 6 months.Subsequent studies yielded conflicting results, in part because of inadequate standardization of the cranberry active ingredient. Current evidence suggests that in older women with a history of recurrent UTI, cranberry products may be effective at reducing the risk of UTI [5,15].

\section{Discussion}

In $25 \%-50 \%$ of women presenting with UTI, symptoms will have recovered or will show spontaneous improvement in 1 week without using antibiotics.

When the diagnosis of symptomatic UTI is in doubt, delaying antibiotic treatment for 1 week but offering supportive treatment such as increased fluid intake is an acceptable therapeutic option [16,17].

Consumption of cranberry has been widely used among healthy women for prophylaxis against UTIs. Some clinical studies have supported its benefits, however the effectiveness of the cranberry on prevention of rUTIs remains controversial.

Although laboratory studies have demonstrated that cranberry juice inhibits adherence of uropathogens to uroepithelial cells $[18,19]$, the clinical use of cranberry juice as aprophylactic in prevention of rUTI remains debated [20]. 
It exists conflicting conclusions from several metaanalyses, in part because clinical and methodological heterogeneity, which can lead to different results.

Both Jepson et al. [6] and Wang et al. [8] results were influenced by differences in population characteristics because patients with complicated UTIs (neuropathic bladder, spinal cord injury and radiotherapy) contributed to a major weight to the overall RR estimate than women with rUTIs. Other special population groups in this studies such as children, pregnant women and elderly also contributed and increased even more the variability of participants. Outcome measures differed in the diagnosis of a UTI and varied the timing of UTI assessments.

In our experience,the use of cranberry in its different methods of administration (diet, juice, tablets) is ineffective for reducing rUTIs. Moreover, we found differences in outcomes in terms of effectiveness of the different commercial preparations of cranberries. In any case, it seems that we get better results when limit the use of cranberry to patientin whom it is proved that E Coli is the major responsible for the UTI.

Although we can not assure patients a reduction in the number of UTI, it seems clear that there is a preventive role of the PAC in selected patients, and that the withdrawal of cranberry in these patients is associated with reinfection by E Coli.

Administration of cranberry-containing products differed in form, daily dosage, PAC content and dosing frequency. It is not clear what is the optimum dosage or method of administration (juice, tablets, capsules). In addition, exist different standardized methods to measure PAC contents of these food preparations. Unfortunately, these methods are not comparable. Standardization would be useful in determining the PAC content of food supplements to achieve more reliable results.

\section{References}

1. Nicolosi D, Tempera G, Genovese C, Furneri PM (2014) Anti-adhesion activity of A2Proanthocyanidins (a cranberry major component) on uropathogenic E. coli and P. mirabilis strains. Antibiotics 3(2): 143-154.

2. Vasileiou I, Katsargyris A, Theocaris S, Giaginis C (2013) Current clinical status on the preventive effects of cranberry consumption against urinary tract infections. Nutr Res 33(8): 595-607.
3. Gupta A, Dwivedi M, Mahdi AA, Nagana Gowda GA, Khetrapal CL, et al. (2012) Inhibition of adherence of multi-drug resistant E. Coli by proanthocyanidins. Urol Res 40(2): 143-150.

4. Blumberg JB, Camesano TA, Cassidy A, KrisEtherton P, Howell A, et al. (2013) Cranberries and their bioactive constituents in human health. Adv Nutr 4: 618-632.

5. Jepson RG, Craig JC (2008) Cranberries for preventing urinary tract infections (review). Cochrane Database Syst Rev.

6. Jepson RG, Williams G, Craig JG (2012) Cranberries for preventing urinary tract infections (review). Cochrane Database Syst Rev 10: CD001321.

7. Jepson RG, Mihaljevic L, Craig JC (2004) Cranberries for preventing urinary tract infections (review). Cochrane Database Syst Rev 2: CD00132.

8. Wang $\mathrm{CH}$, Fang CC, Chen NC, Liu SS, Yu PH, et al. (2012) Cranberry-containing products for prevention of urinary tract infections in susceptible populations. Arch Intern Med 172(13): 988-996.

9. Beerepoot MAJ, Geerlings SE, van Haarst EP, Mensing van Charante N, ter Riet G (2013) Nonantibiotic prophylaxis for recurrent urinary tract infections: a systematic review and metaanalysis of randomized controlled trials. J Urol 190(6): 1981-1999.

10. Maki KC, Kaspar KL, Khoo C, Derrig LH, Schild AL, et al. (2016) Consumption of a cranberry juice beverage lowered the number of clinical urinary tract infection episodes in women with a recent history of urinary tract infection. Am J Clin Nutr 103(6): 1434-1442.

11. Hisano M, Bruschini H, Nicodemo AC, Srougi M (2012) Cranberries and lower urinary tract infection prevention. Clinics 67(6): 661-667.

12. Singh I, Gautam LK, Kaur IR (2016) Effect of oral cranberry extract (standardized proanthocyanidinA) in patients with recurrent UTI by pathogenic E. coli: a randomized placebo-controlled clinical research study. Int Urol Nephrol 48(9): 1379-1386.

13. Sánchez Ballester F, Ruiz V, López E, Domenech C, Escudero E, et al. (2013) Cysticlean ${ }^{\circledR}$ a highly pac standardized content in the prevention of recurrent 
urinary tract infections: an observational, prospective cohort study. BMC Urol 13: 28.

14. Occhipinti A, Germano A, Maffei ME (2016) Prevention of Urinary Tract Infection with Oximacro, A Cranberry Extract with a High Content of A-Type Proanthocyanidins: A Pre-Clinical DoubleBlind Controlled Study. Urol J 13(2): 2640-2649.

15. Avorn J, Monane M, Gurwitz JH, Glynn RJ, Choodnovskiy I, et al. (1994) Reduction of bacteriuria and pyuria after ingestión of cramberry juice. JAMA 271(10): 751-754.

16. Knottnerus BJ, Geerlings SE, Mollvan Charante EP, terRiet G (2013) Women with symptoms of uncomplicated Urinary tract infection are often willing to delay antibiotic treatment. BMC Fam Pract 14: 71 .
17. Mody L, Juthani-Mehta M (2014) Urinary tract infections in older women: a clinical review. JAMA 311(8): 844-854.

18. Schmidt DR, Sobota AE (1988) An examination of the antiadherence activity of cranberry juice on urinary and nonurinary bacterial isolates. Microbios 55(224-225): 173-181.

19. Zafriri D, Ofek I, Adar R, Pocino M, Sharon N (1989) Inhibitory activity of cranberry juice on adherence of type 1 and type P fimbriated Escherichia coli to eucaryotic cells. Antimicrob Agents Chemother 33(1): 92-98.

20. Aydin A, Ahmed K, Zaman I, Khan MS, Dasgupta P (2015) Recurrent urinary tract infections in women. Int Urogynecol J 26(6): 795-804. 